\title{
"Barriers and opportunities for hi-tech innovative small and medium enterprises development in the 4th industrial revolution era"
}

\begin{tabular}{|c|c|}
\hline \multirow{8}{*}{ AUTHORS } & Larysa Antoniuk (D https://orcid.org/0000-0003-1389-4720 \\
\hline & R http://www.researcherid.com/rid/J-7149-2015 \\
\hline & \multirow{3}{*}{$\begin{array}{l}\text { luliia Gernego } \\
\text { Vyacheslav Dyba } \\
\text { Yevheniia Polishchuk iD https://orcid.org/0000-0002-6133-910X }\end{array}$} \\
\hline & \\
\hline & \\
\hline & R http://www.researcherid.com/rid/J-5444-2018 \\
\hline & \multirow{2}{*}{$\begin{array}{l}\text { Yuliia Sybirianska i https://orcid.org/0000-0003-4075-3560 } \\
\text { R http://www.researcherid.com/rid//-9157-2018 }\end{array}$} \\
\hline & \\
\hline ARTICLE INFO & $\begin{array}{l}\text { Larysa Antoniuk, luliia Gernego, Vyacheslav Dyba, Yevheniia Polishchuk and } \\
\text { Yuliia Sybirianska (2017). Barriers and opportunities for hi-tech innovative small } \\
\text { and medium enterprises development in the 4th industrial revolution era. } \\
\text { Problems and Perspectives in Management, 15(4), 100-113. } \\
\text { doi:10.21511/ppm.15(4).2017.09 }\end{array}$ \\
\hline DOI & http://dx.doi.org/10.21511/ppm.15(4).2017.09 \\
\hline RELEASED ON & Wednesday, 20 December 2017 \\
\hline RECEIVED ON & Sunday, 05 November 2017 \\
\hline ACCEPTED ON & Wednesday, 06 December 2017 \\
\hline & $(\mathrm{cc})$ EY-NC \\
\hline LICENSE & $\begin{array}{l}\text { This work is licensed under a Creative Commons Attribution-NonCommercial } 4.0 \\
\text { International License }\end{array}$ \\
\hline JOURNAL & "Problems and Perspectives in Management" \\
\hline ISSN PRINT & $1727-7051$ \\
\hline ISSN ONLINE & $1810-5467$ \\
\hline PUBLISHER & LLC "Consulting Publishing Company "Business Perspectives" \\
\hline FOUNDER & LLC “Consulting Publishing Company "Business Perspectives" \\
\hline & 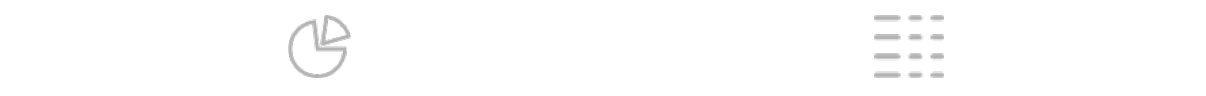 \\
\hline NUMBER OF REFERENCES & NUMBER OF FIGURES \\
\hline 21 & 5 \\
\hline
\end{tabular}

(C) The author(s) 2023. This publication is an open access article. 


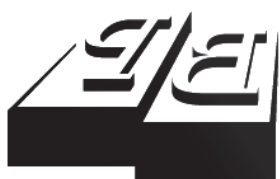

BUSINESS PERSPECTIVES

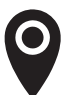

LLC “CPC "Business Perspectives" Hryhorii Skovoroda lane, 10, Sumy, 40022, Ukraine

www.businessperspectives.org

Received on: $5^{\text {th }}$ of November, 2017 Accepted on: $6^{\text {th }}$ of December, 2017

(C) Larysa Antoniuk, Iuliia Gernego, Vyacheslav Dyba, Yevheniia Polishchuk, Yuliia Sybirianska, 2017

Larysa Antoniuk, Vice-rector, Kyiv National Economic University named after Vadym Hetman, Ukraine.

Iuliia Gernego, Ph.D. in Economics, Associate Professor, Kyiv National Economic University named after Vadym Hetman, Kyiv, Ukraine.

Vyacheslav Dyba, Doctor of Economics, Professor, Kyiv National Economic University named after Vadym Hetman, Ukraine.

Yevheniia Polishchuk, Doctor of Economics, Professor, Kyiv National Economic University named after Vadym Hetman, Ukraine.

Yuliia Sybirianska, Ph.D. in Economics, Associate Professor, Kyiv National Economic University named after Vadym Hetman, Ukraine.

\section{(ㄷ)(ㄱ)}

This is an Open Access article, distributed under the terms of the Creative Commons Attribution 4.0 International license, which permits unrestricted re-use, distribution, and reproduction in any medium, provided the original work is properly cited.
Larysa Antoniuk (Ukraine), Iuliia Gernego (Ukraine), Vyacheslav Dyba (Ukraine), Yevheniia Polishchuk (Ukraine), Yuliia Sybirianska (Ukraine)

\section{BARRIERS AND OPPORTUNITIES FOR HI-TECH INNOVATIVE SMALL AND MEDIUM ENTERPRISES DEVELOPMENT IN THE 4TH INDUSTRIAL REVOLUTION ERA}

\begin{abstract}
High-tech innovative SMEs' development plays crucial role in economic growth of every country. It creates new work places and infrastructure, motivates people for creating new ideas. At the same time, SMEs still face with a huge number of problems in the business performance. The purposes of the research are: to define main barriers for high-tech SMEs' development in the 4th industrial revolution era (4IR); to work out recommendations for policy-makers towards intensification of SMEs' potential.

For this purpose, the authors reviewed studies devoted to the SMEs' innovative development and revealed that main barriers of SMEs' development are related to inefficient government support in this sphere. In order to work out recommendations for Ukrainian policy-makers in the area of SMEs' development, the authors conducted a survey of local high-tech SMEs and on the basis of SWOT-analysis distinguished the main directions for their further improvement. Finally, a set of recommendations for improving SMEs' environment in Ukraine, taking into consideration the challenges of the 4th IR, was developed.
\end{abstract}

Keywords $\quad \begin{aligned} & \text { innovation, SME, Fourth Industrial Revolution, high- } \\ & \text { tech, government support }\end{aligned}$

JEL Classification O30, O38, O11

\section{INTRODUCTION}

Nowadays, people live in the early days of the upgrading digital economy. Despite this fact, it has already had huge impacts on the development of business and economies during recent years. Moreover, digital transformations and rapid fundamental changes in business are among dominant features of the Fourth Industrial Revolution (4IR) of the 21th century. The digital capability model was developed as the new way of industrial automation aimed at transformation of technological process and changing humans' roles in it. One of the most significant modern peculiarities is that robots function as human substitutes in a wide range of industries. Upgrading of digital business concept is flexible, full of innovations and experiments. Digital concept will create new innovative business opportunities and boost their productivity.

Nevertheless, some SMEs move beyond existing trends due to their diversified and unpredictable activities. As a result, there are changes in the whole area. In particular, new forms of doing business, including cloud systems and services, and cooperation between high-tech SMEs and different stakeholders, are developed. There are new types of services and products, including Internet of things, new ways of 
usage and commercialization of the existing products and services (on-line television, digital advertising, social networking, financial technology, e-commerce, online education, automated monitoring and control systems, game played processes and services, technologies of environmentally benign future and energy-saving life, optimizing the life and business processes).

However, only a few business structures are ready to be adapted to ongoing transformations. SMEs are among the latter as one of the most flexible and capable for innovations segments of the business. The new wave of digital technologies brings both challenges and opportunities for SMEs. There is a need to study the nature and peculiarities of the 4IR changes. It will help high-tech innovative SMEs decision makers to manage their business under conditions of current global economic competitiveness.

\section{LITERATURE REVIEW}

Recent studies show the far-reaching integration of information and operational technologies. Surveys conducted by Schwab (2015, 2017), Richards (2016), Dittrich (2016), Economist Intelligence Unit (2010) and UNCTAD (2017) experts show the main specifications and possible effects of the 4IR. The current situation and man jor problems of information technology within industrial area in Ukraine are analyzed by Frolov et al. (2017). Yurynets (2016) investigates the factors for economic growth, including the influence of Research and Development on GDP growth.

Notwithstanding, few studies have explored in the field of high-tech innovative SMEs' development. Economic problems of business function development in the sectors of national economy are studied by Britchenko et al. (2012). Bloem et al. (2014) and Moavenzadeh (2015) discover benefits of upgrading digital economy for large enterprises. The companies by size are distinguished in Global Enterprise Recognition Report (2015).

SMEs impact on economic growth is provided by the Edinburgh Group researches (2011). Kushnir (2010) provides an overview of data at micro, small, and medium enterprise levels in different economies. The study by Chien (2012) deals with startups ability to monetize their patents in the USA. The Kauffman Index of Startup Activity indicates the meaning of startup initiatives for economic health (Fairlie \& Reedy, 2016). The level of value added generated by EU28 SMEs is studied by Muller (2016). Wang (2016) defines the biggest obstacle to SMEs growth. In the article by Olefirenko (2016), scientific and methodic approach to optimize distribution expenses of the innovatively ac- tive enterprises in Ukraine is developed. Still, there is not enough previous studies which have been concentrated on this issue in Ukraine. Thus, this requires new research about SMEs' development in Ukraine in the context of the 4IR.

\section{METHODOLOGY}

To determine obstacles and opportunities of hightech innovative SMEs' development in the era of the 4IR we used different scientific methods and proceeded four following steps. Firstly, we have chosen statistical reports of authoritative institutions such as private companies, consulting and rating firms (e.g. Deloitte, Edge, Moody's, Price Waterhouse), international organizations (UNIDO, OECD, the World Bank, the European Commission), NGOs and others. Using induction method, we identified main rising trends of high-tech SMEs and disclosed main factors that affect their evolution and development. To prove the importance of SMEs, we regarded the number of enterprises, employment and value added by SMEs and Large enterprises in the EU-28 by using comparative method. Secondly, we analyzed public policies in countries with welldeveloped SMEs sector and, using system method, classified types of SMEs of government support. Thirdly, by means of method of statistical observation, we conducted survey of high-tech innovative SMEs to define their main problems in doing business. Fourthly, based on the results of SWOTanalysis of SMEs' government policy in Ukraine we determined possible types of support that could be implemented in Ukraine; then we formulated recommendation for Ukrainian policy-makers in the field of SMEs' development that could help to overcome barriers and meet opportunities on the way toward the era of 4IR. 


\section{RESULTS}

While the First Industrial Revolution was accompanied by industrial growth, the Second was connected with the invention of the electricity and mass production development (the latter were mainly connected with large enterprises with their capability to attract additional resources and to produce more items (Bloem et al., 2014; Moavenzadeh, 2015). The Third Industrial Revolution or the Digital Revolution, which began in the second half of the 20th century, is still ongoing nowadays and includes the development of personal computer, the Internet and other ICT. And in recent years, there has been an increasing interest to high-tech innovative SMEs as participants of industrial process, which are capable to innovations and able to create new jobs.

A dramatic increase in digital industry development has been observed over the last century. On the one hand, the Fourth Industrial Revolution means the logical continuation of the Third IR, because digital technologies introduction and development are among its main features. On the other hand, this era creates the unique opportunities to disrupt the current industry structures, to improve the existing human communication and conflict resolution systems.

The main influences of the 4IR will be multiplied by the globally technology breakthroughs in areas such as artificial intelligence, robotics, the Internet of things, autonomous vehicles, 3-D printing, nano and biotechnologies, material science, energy storage, and quantum computing (Schwab, 2015; Schwab, 2017; Richards, 2016). These inventions are targeted to transform the production-consumption process from step-bystep to integrated interdependent process. Instead of the previously functioning linear productionconsumption model, a new hyper connected platform is being created. The latter means a deeply integrated system of planning, $\mathrm{R} \& \mathrm{D}$, production, marketing, sales \& services, which drives all components of productivity improvement in the value chain, developing shorter life cycle of a product (KIET, 2017).

As already mentioned above, among important features of high-tech SMEs activity are the flexi- bility and innovative capability because they need fewer resource, are less structured and more capable for improvements and experiments than large corporations. The EU Commission surveys indicate that more than $90 \%$ of SMEs perceive they are lagging behind in the field of digital innovations (Dittrich, 2016). The global production of ICT goods and services amounts to an estimated 6.5\% of GDP in 2017. Sales of robots are at the highest level ever, worldwide shipments of threedimensional printers more than doubled in 2016 (UNCTAD, 2017). Therefore, SMEs offer a huge potential for technologies in the digital age, but in developing countries, the conditions for their creation are inadequate.

Based on Shift Index research, conducted by the Deloitte Center for the Edge, we summarized the fundamental factors inherent in the information era that influence the modern progress of the high-tech SMEs:

significant increase in productivity over the last 45 years;

- cheapening of the digital technology;

- decrease in the cost of computing power;

- fall of the cost of storing information;

- downturn of the cost of the data transfer rate;

- $\quad$ significant rise of the Internet penetration rate (more than 50 times over the last 20 years).

The global audience of Internet users (3.5 billion people) and billions of smart phones, tablets, laptops have already created necessary infrastructure for the business breakthrough development in the information era. The world advanced information infrastructure in combination with the listed above factors of SMEs' development are causing the three main global trends in hightech field:

- rapid development of artificial intelligence (AI). Most of the activities in the high-tech sector are provided with AI, cyber security and searching systems, interconnection of users of automated control and recognition; 


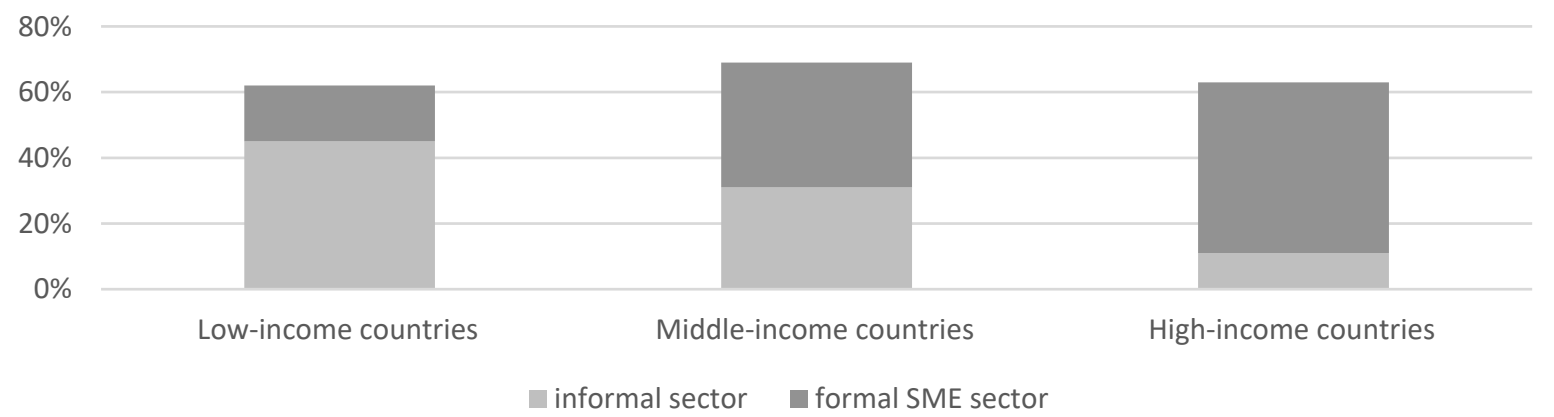

Figure 1. Contribution of SMEs to GDP (middle values) (Growing the global economy through SMEs)

- $\quad$ spreading of cloud services that are used by most Internet users. Moreover, cloud data storage becoming an integral part of most businesses;

- development of nanotechnologies, which primarily improve medicine, pharmacology and biotechnology. These industries are technologically saturated; they transform the production and usage of most materials in the modern world.

Nowadays, in the world of intellectual capital, innovations are the major driver of growth for all types of organizations and economies. Since innovation implies a high degree of risk, most of the innovative ideas are commercialized in the form of startups or in a small scale. According to the Global Entrepreneurship Monitor (GEM) research, hightech business creates on the average three times more jobs in the long-run period than a SME, which operates within already existing traditional industries.

From mentioned GEM study, we can distinguish five main reasons of why high-tech SMEs become significantly important in the global economy:

- an innovative component, since startups are the most adaptable type of business to implement innovative breakthrough ideas. They significantly contribute to the rapid technological development of the world. In addition, under global competition, countries invest in development of innovative centers to attract more startups that have positive impact on the development of innovations in the country;

- growth of the national economies competitiveness. Since startups are the most dynamic and promising companies, they contribute to the export potential, economic security and innovation of the country in which they operate. Creation and development of new technologies and services can provide a leading position in new market niches;

- innovative and research ecosystems development inside the country. Like any high-tech business, startups are closely linked to the scientific activities of educational and research institutions. The development of SME stimulates researches and development of technoparks, universities, academies, research and scientific centers;

- a positive contribution to the social development of the society. The development of innovative entrepreneurship changes values of the society, educates it on the basis of knowledge, entrepreneurship and creativity. Attraction of foreign investors and entrepreneurs helps to increase qualification of local specialists by exchanging experience and establishing new business contacts;

- creating jobs and economic growth stimulation (Figure 1).

We should mention that crisis of 2008 and the subsequent recession of most economies in the world had a negative impact on startup activity. It has caused a lack of capital in all markets. In addition to that, the overall decline in the economies of the countries significantly reduced the purchasing power of the population, which greatly reduced the value of products and services that were new and untested. According to the Kauffman Foundation's research (Figure 2), the dynamics of the startup activity fell sharply even in the USA and began to recover only in 2014. 


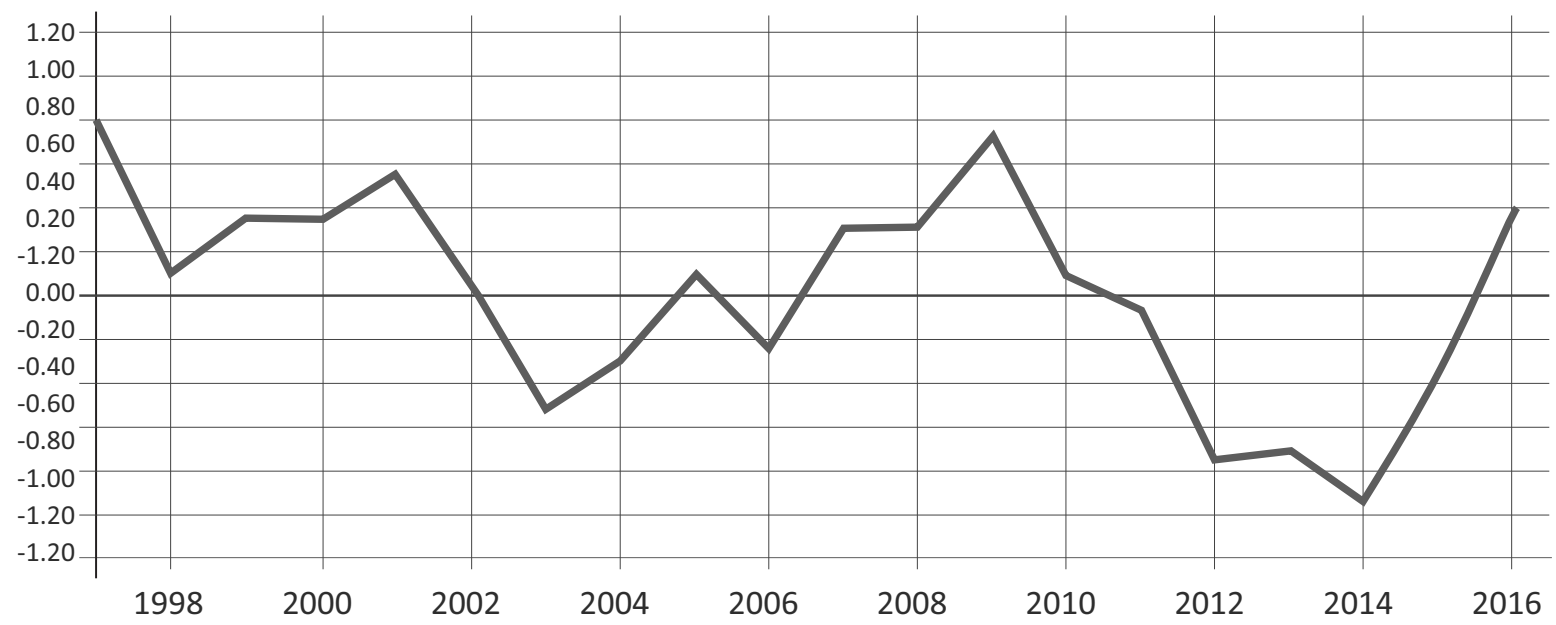

Figure 2. The Kauffman Index of startup activity (1997-2016)

Figure 2 shows that upward trend persists in 20152016. Economic stabilization, cheaper loans, increased investments in research and development stimulate more and more people to run startups.

The development of SME business is closely related to the economic, political and demographic aspects of each country. More than $95 \%$ of all enterprises in the world are SMEs (it depends on the applied criteria in each country). They employ approximately $60 \%$ of all private-sector workers.

The role of SME businesses in the European Union (EU-27) in 2015 shows its structural importance (Table 1). It covers $99.8 \%$ of all enterprises, employs $66.8 \%$ of all private-sector jobs and generates $57.4 \%$ of the total value added (calculated as the value of their proceeds minus the cost of their intermediate consumption), which is created by private sector. But the contribution of SMEs in economic development varies from country to country. It ranges from $16 \%$ of GDP on the average for countries with low GDP (where SME sector is usually large, but mainly operates in the shadow market, so official data is often lower than the real).

According to the World Bank and the International Finance Corporation, researches the largest number of SME businesses is concentrated in Eastern Asia, Oceania and high-income OECD countries. It is important to note that high-income OECD countries show higher average density and higher share of high-tech SME business compared with other groups of countries highlighted in the study. Therefore, these countries invest in the most innovative business at the early stages of development.

The Edinburgh Group has tried to capture the contribution of SME businesses to the GDP of countries based on the World Bank database. They considered the official market and roughly estimated shadow market (which is extremely high in low-income countries). In comparison to a large business, the contribution of small manufacturing business to GDP per enterprise will be smaller. It is more labor-intensive and usually has a lower

Table 1. The number of enterprises, employment and value added by SMEs and large enterprises in the EU-28 in 2015

\begin{tabular}{|c|c|c|c|c|c|c|}
\hline Indicator & Micro & Small & Medium & Total SMEs & Large & Total \\
\hline Number of enterprises & $21,356.252$ & $1,378.702$ & 224,647 & $22,959.600$ & 44.458 & $23,004.059$ \\
\hline Share in total & $92.8 \%$ & $6.0 \%$ & $1.0 \%$ & $99.8 \%$ & $0.2 \%$ & $100 \%$ \\
\hline Number of people employed & $40,057.408$ & $27,503.428$ & $23,170.352$ & $90,731.132$ & $45,168.732$ & $135,899.904$ \\
\hline Share in total & $29.5 \%$ & $20.2 \%$ & $17.0 \%$ & $66,8 \%$ & $33.2 \%$ & $100 \%$ \\
\hline Value added (EUR billion) & $1,453.926$ & $1,233.270$ & $1,250.907$ & $3,938.103$ & $2,923.873$ & $6,861.976$ \\
\hline Share in total & $21,2 \%$ & $18,0 \%$ & $18,2 \%$ & $57,4 \%$ & $42,6 \%$ & $100 \%$ \\
\hline
\end{tabular}




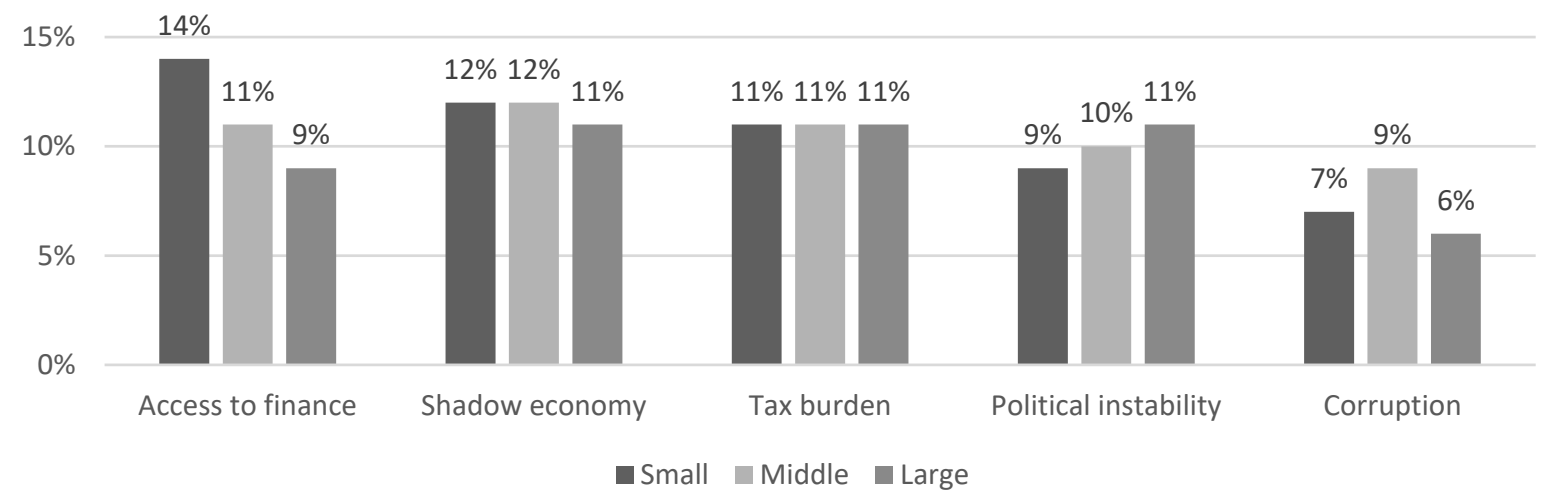

Figure 3. Main obstacles for SMEs growth in developing countries (Wang, 2016)

productivity than large corporate sector, that is why SMEs need more labor resources.

Thus, SME sector compensates shortage of significant capital investments through the labor, which is beneficial to low-income countries where there is a lack of capital, but large number of unemployed. Under such conditions, SMEs can be a long-term development engine for developing countries. The conclusion of research by the World Bank, which covered 47,745 businesses from 99 countries where the size of SMEs is from 5 to 250 employees, could be evidence of that fact. They found out that the total growth in the number of employed provided by SME during $2008-2014$ was at an average $85 \%$.

Modern peculiarities of the SME market and technology are primarily determined by the progress of information in the world. To estimate the volumes and growth rates of high-tech SME businesses we could compare the growth index of Silicon Valley innovation business and other businesses on the basis of international rating agency Moody's. Based on this comparison, we can observe high growth of SME high-tech businesses. An innovative business often creates a new market or niche, which is unsaturated at the moment but they hardly enter a market where any significant potential for growth couldn't be observed.

The role of factors that affect the potential employer's decision to start own business has been explored by Amway international company within the framework of the 2015 AGE Global Enterprise Recognition Report. The result of the study shows that among the main determinants are as follows:
- potential debt burden $-41 \%$ of respondents;

- the treat of economic crisis $-29 \%$;

- probable inability to find a job in case of failure $-16 \%$;

- probability of law problems, contradictions with the law $-16 \%$;

- potential personal disappointment in business initiative $-15 \%$;

- necessity of making decisions - 13\%;

- probability of absence of second chance in case of failure of the first attempt $-8 \%$.

As part of a study, conducted by Institute of Economic Studies, Faculty of Social Sciences Charles University in Prague (2016), a review of the SME businesses environment was provided. The research was conducted on the basis of the World Bank database "Enterprise survey dataset". It determined the main factors that influence the activity of SMEs in developing countries (Figure 3).

Most problems that business faces are similar for different sizes of businesses, but they have different levels of cruciality. For example, the issue of financing is the most sharp for a rapidly developing SME, but at the same time not sufficiently guaranteed for creditors and investors. As the business grows, the debt/equity ratio improves. It means that business has already won a part of the market and has enough assets to meet its obligations. 
On the other hand, political instability as a critical fact is more often defined by large business than SMEs. SME acute is often less dependent on the general macroeconomic policy pursued by political power because of its local specifics. This applies to government programs with the participation of the private sector, public procurement tenders, public infrastructure projects, etc. Political instability violates the healthy functioning of the SME business ecosystem. It starts to cause things as inflation, devaluation of the national currency, general stagnation of the economy, adverse changes in the legislation directly to SME, abolition of tax privileges, increase in the tax burden, bureaucratization, etc.

External factors such as shadow economy and tax system, in terms of their level of influence, are inferior to the problems of financing. But they are almost equally important for all sizes of enterprises, although for SME businesses these questions are sharper. SMEs are very sensitive to things such as the shadow economy. Illegal import of products/ raw materials by unfair market participants allows illegal increase in the business margin saving on custom duties, to sell non-licensed or non-certified goods, avoid taxation, decline the tax base, conduct informal cash transactions, etc.

SMEs that operate in a legal and transparent market, have no resources to fight with unfair competition through the judicial system, propaganda/ promotional campaigns or significant investments aimed at increasing operational efficiency. Therefore, unfair competition leads to a decline in sales and profitability of the legally operating business. It also reduces tax and customs revenues, negatively affects the fiscal policy of the country and reduces its economic efficiency.

The last but not the least factor generated by the World Bank is corruption, which adversely affects the business. In countries with high probability of giving bribes to officials there is a small number of SMEs.

Experts from UNIDO and OECD (2016), emphasize that many SMEs carry out their activities outside the official market. Therefore, one of the main goals of the governments from different countries is to create an institutional, organizational and regulatory environment that would encourage the SMEs to legitimate economic activity.

The governments cannot form their own "entrepreneurial culture", but through their activity, they can either slow down or stimulate its improvement. The main difficulty in SMEs' regulation is a remarkable differentiation of this sector of entrepreneurial activity. Hence, it is important not only to have impact on individual business groups but also to create a socially responsible environment with a well-developed entrepreneurial culture, where development and improvement will be initiated and developed by bottom-up approach.

While forming public policy it is important to realize that SMEs will function effectively if:

- a culture of entrepreneurship will be brought up in society, which will encourage both individual and collective initiatives and innovations. Policy makers must understand that financial education is the fundamental thing in building the same culture;

economic, political and social climate will be ensured, which will provide a high level of startups and help existing businesses to survive;

- high-quality, socially responsible and innovative business will prevail in the overall mass of SMEs;

- there will be friendly economic and social climate that will stimulate the growth and development of existing SME businesses;

- all SMEs' stakeholders will sympathize to business and operate as an entrepreneur.

The last point is especially important for SMEs, because they rely on high level of sympathy, support and protection from government, the educational system, regulators, financial institutions, individual professionals, large corporations, etc. A favorable environment for SMEs' activities could be created only if all stakeholders have common entrepreneurial spirit.

In the research, we argue to discover the particular importance of SMEs' environment component such 
as patenting. The patenting is probably more related to high-tech and innovative startups than to other environmental components due to its "double nature". On the one hand, it creates a fundamentally new product, service technology, but, on the other hand, it tries to replace or modify existing one. Therefore, there are two important issues, namely: to protect own innovation and to avoid the restriction of already existing competitors' patents.

The problem is that the young businesses do not have sufficient knowledge and resources to patent their products and services in right way. The solution to this problem depends on external factors, in particular: the patent rights in the country/region, the activity of consulting and legal companies in stimulating small business development, the general business culture and fairness of competition on the market, the availability of funds necessary for participation in litigation, dispute resolution and receipt necessary documents.

The business arises within innovative ecosystem that largely determines its further development, potential risk levels and the chance of its realization. Moreover, startup turns into booming business only under the influence of highly developed infrastructure and all-round business support, which allows to decrease negative influence or to avoid risks at all. The major imperatives of SMEs' development are: lack of financing, shadow economy development, corruption, tax regime, country macroeconomic and political stability, patent law accomplishment and level of other stakeholders qualitative involvement to its implementation.

As it was mentioned, SMEs play a crucial role in the global economy. Especially, small business that has a significant impact on the highly technological sector. Therefore, this area of small business activity has a pivotal role in the context of ICT exponential development. Moreover, the format of SMEs and startups is particularly competitive in an era of constant changes and transformation. A small business success and competitiveness depend on critical features that are the subject of our investigation, namely:

- mobility;

- low capital intensity;
- a minimal potential losses volume from the initial launch failure;

- a well-developed infrastructure or powerful corporate add-ons requirements that are not always essential for a startup initiation in underdeveloped countries;

- a lack of procedural, corporate and bureaucratic restrictions that differs from large companies;

- a lack of intense internal competition between high-tech SME businesses. Cooperation between startups, young entrepreneurs and consulting corporations make their idea competitive as against large companies. SMEs are ready to donate part of their future revenues for the sake of strategic partnership and their idea implementation. Modern entrepreneurial culture has caused that simply ideas commercialization is less important for startups and breakthrough project managers than social problem solution, additional value creation and improvement in the people's life;

- a number of potential breakthrough ideas do not depend on place of employment, country of origin, age or gender.

Therefore, everyone is able to start a small business. The formation of new entrepreneurship culture is associated with everyone, who seriously considers the possibility of starting own business. SME original ideas are highly diversified worldwide due to the cultural differences. In particular, different countries need different problems to solve. The need of satisfaction depends on the segment of the population, differences in education and culture cause a variety of values and development trends, etc.

In addition, main modern post-industrial information society features are able to eliminate some of the SME weaknesses. For example, SMEs are not local any more due to the yearly Internet penetration increase, including: $3 \mathrm{G}$ and $4 \mathrm{G}$ Internet worldwide availability, Wi-Fi institutional spreading, cloud services that become the main means for significant data volumes exchanging and collaborative environment development. 
Moreover, SMEs have fewer problems with the lack of funds for promotion and advertising. A large number of global social networks have extremely simplified and boosted the distribution of information about an innovative, competitive and unique product. In addition, SMEs have new sources of funding. For instance, over the past decades, sources of funding such as crowd funding became more widespread (international online platforms - Kickstarter, Indiegogo). The number of venture funds, business angels, business incubators and accelerators, who invest in promising high-tech startups, has also increased.

Thus, high-tech SME is developing with the entire sector and the sector is transforming with the emergence of new breakthrough ideas and products. All SMEs' peculiarities and changes can be considered as features of the entire sector, because SME's business is an integral part of it.

According to OECD data, about $30-60 \%$ of all small manufacturing businesses in the OECD countries have initiated new or improved products that can be characterized as innovative. SME business tends to drive an increase in $R \& D$ in most OECD countries and its share in R\&D is about $17 \%$. This proves the positive impact of SMEs and high-tech startups on the country's scientific and technological development. SMEs' R\&D stimulate the emergence of new forms of cooperation among the government, social and private sectors and SMEs. In particular, separate state agencies are established in the areas of cooperation with high-tech SMEs. Industrial parks, business accelerators, incubators based on educational institutions, separate departments in large corporations, which attract SMEs to their R\&D centers are also established.

So, the impact of SMEs on the world economy is increasing year by year, changing the entrepreneurial culture, the functioning of markets, the climate in the labor market, and creating completely new markets and technologies. At the same time, trends in global information and technology markets have significant impact on SMEs in the high-tech sector.

SME's sector growth highly depends on government support. There are different roles of govern- ment in supporting innovations in different countries (Figure 4). Its crucial impact on their development has to provide favorable climate (political, legislative and economic factors that effect development of innovations).

Figure 4 shows that there are many instruments among economic factors that are used in different countries according to the general policy of innovation development. Considering business grant support, example of Ireland is especially noteworthy. In Ireland, the government offers grants for researches in science to big IT companies such as Dell and Intel on interest-free basis for fixed investment for SMEs. The government creates market supply and requests SMEs to design innovations by signing a contract with them. Special funding programs also exist in France, Germany and Switzerland. The funding is directed at supporting innovations in specific sectors of economy. French government provides cash grants, loans, tax credits, reduced tax rates, accelerated depreciation on $\mathrm{R} \& \mathrm{D}$ assets, patent-related incentives. Portugal and Spain have large set of fiscal instruments for all legal entities for innovation support. Exclusive SMEs' privileges are used in Great Britain, including cash grants, tax credit, patent-related incentives, and accelerated depreciation on R\&D assets. Other type of support is related to tax holidays. For example, Chinese government supports SMEs' innovations by offering full tax exemption during the first profitable year and tax payments decrease of $50 \%$ over the next 3-5 years. The same is in India. There is also full tax exemption up to 5 years and decrease of $50 \%$ for SMEs from 6 th to 15 th years of functioning. SMEs take advantages within 7 years of government tax holiday in Israel. SMEs frequently use tax credits, cash grants, income tax withholding incentives, patentrelated incentives, tax exemptions, reduced tax rates, tax deduction, including super deductions, loans, VAT reimbursements and reduced SSC rates in Belgium. Hungary provides cash grants, reduced tax rates, tax credit, patent-related incentives, reduced SSC, tax deduction, including super deductions to strengthen SMEs' capabilities. Government policy of SME development in the Netherlands allows using reduced tax rates, tax credit, patent-related incentives, reduced SSC rates, tax deduction (including super deduction), accelerated depreciation on R\&D assets, cash grants. Compensations for losses of profits are provided in Singapore. 


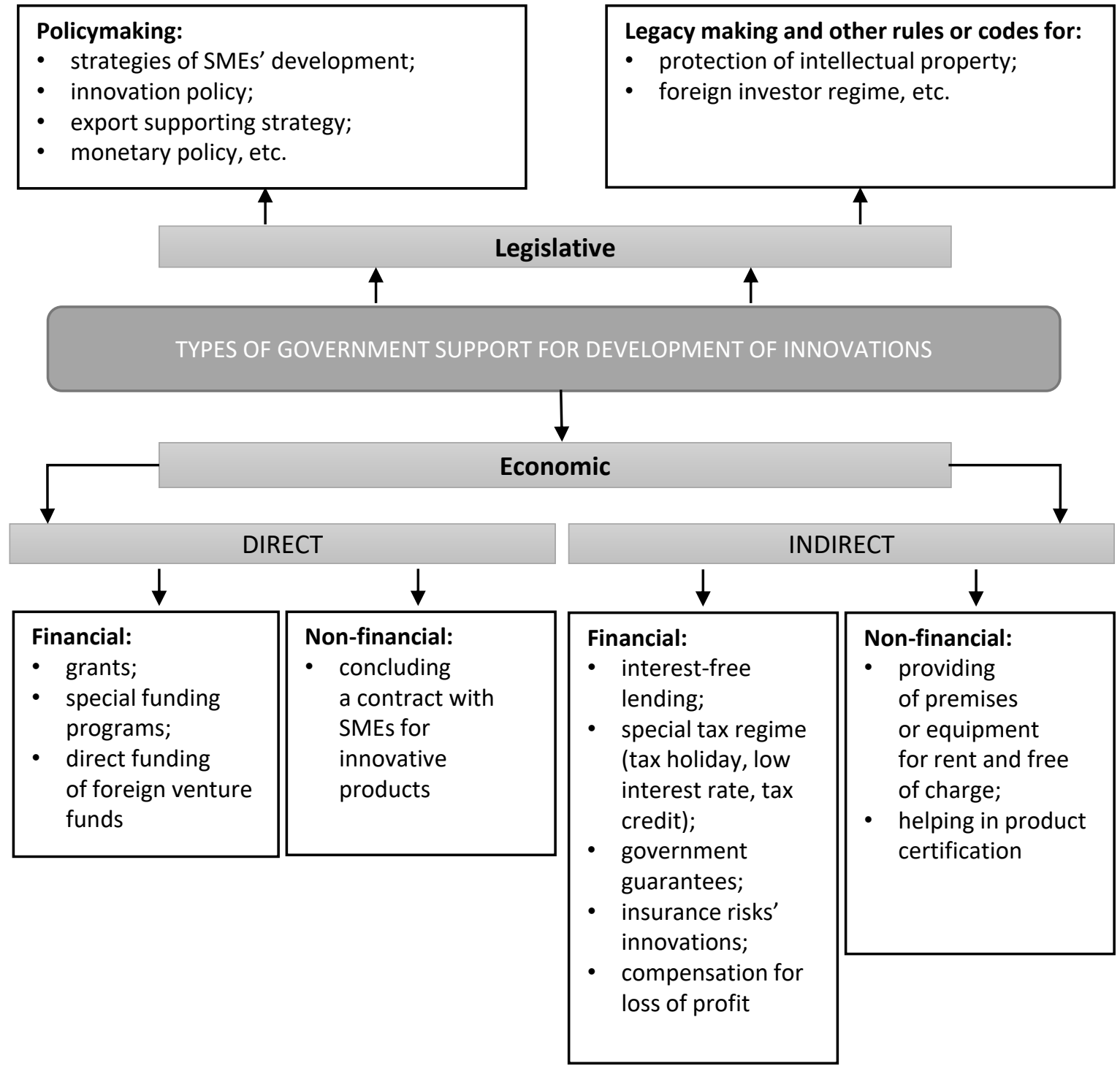

Figure 4. Types of government support for development of innovations

In the era of 4IR, the Ukrainian economy competitiveness in the international market depends on the innovative technological business development. The share of SMEs that introduce innovative products or processes has increased from $7.4 \%$ in 2015 to $7.9 \%$ in 2016 . However, such growth is not enough to enable small business to drive economic growth in Ukraine. This reflects the need of the innovative SME development policy implementation and understanding small business nature. Therefore, our research provides a specialized survey of Ukrainian technological startups. A list of questions related to directions of business activity, funding and taxation and the most urgent needs or changes were prepared within this research. More than 20 representatives of active high-tech SMEs were interviewed. As a result, the largest share of respondents (30\%) are related to computer technology business (Figure 5).

Ukrainian high-tech SMEs' representatives point out the key obstacles for their businesses, namely: imperfect regulatory framework ( $70 \%$ of respondents), problems with the promotion of a product or service $(50 \%$ of respondents), lack of investments ( $45 \%$ of respondents). At the same time, they identify the activities of foreign individuals and organizations (55\% of respondents), public and business organizations ( $45 \%$ of respondents), IT clusters, business incubators and accelerators 


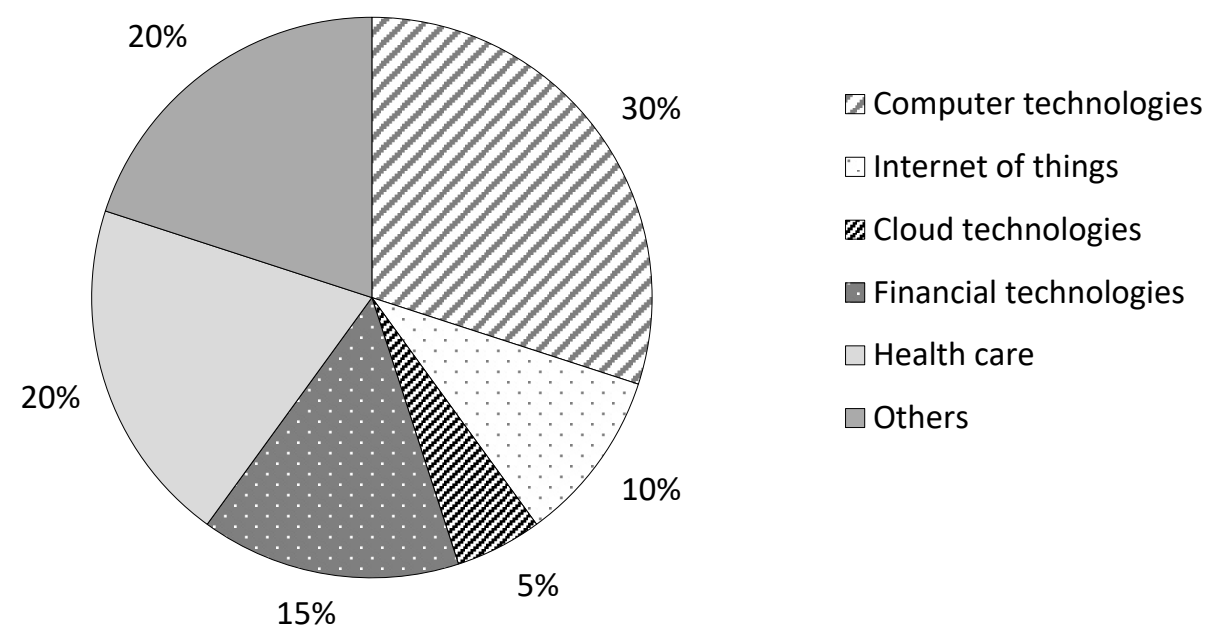

Figure 5. Areas of surveyed small innovative business activity

(40\% of respondents) as the most contributing factors to their businesses development. It is important to underline that none of the respondent benefit from the government authorities' activities. Only $10 \%$ of respondents benefits from the activities of individual government officials. This indicates a weak government involvement in specific problems of high-tech SMEs solving and inefficient mechanism of cooperation between government and business. As a result, $65 \%$ of the respondents approved the necessity of state programs for SMEs' support through grants, investments and cheap loans implementation to improve businessenvironment for innovative enterprises. On the other hand, none of the respondents defines the state as business-partner or co-owner. The largest part of respondents (30\%) intend to implement their own business initiative on their own, which indicates a high level of distrust of entrepreneurs in other market participants. Only 25\% and 20\% of respondents are ready to cooperate with venture or direct investment funds and a large business, respectively. However, business angels and other private investors are defined as the main source of financing used by $45 \%$ of respondents. Other businesses were funded by business incubators and accelerators (25\%) and with non-bank loans (20\%).

At the same time, Ukraine has great advantages comparing to other countries, including high quality human capital; competitive high-tech developments; space and aviation industry; outstanding math and biotech schools; leading posi- tion in the IT industry in a global market. Ukraine took the third place in the world after the USA and India by the number of certified IT specialists. This proves that Ukraine has chances to be an important player on the innovation market.

The policy of SMEs' development has to be an integral part of national structural reforms in Ukraine. This is confirmed by a benchmarking assessment of the implementation parameters of development policies in the Eastern Europe. This policy will facilitate the sources diversification for economic growth in the country. SME could play an important role among such sources both in the medium-term and long-term framework. The analysis of the weak and strong points allows us to define the prospects for Ukraine and the friction points to work at (Table 2).

Every EU country has its own roadmap of development strategies to maximize their opportunities (Figure 6), because they understand the importance of SMEs for improving economic competitiveness, restoring sustainable growth, developing an enabling environment for business, and attracting new investments to the country. The potential of economic growth depends on effective government policy in the area of SMEs.

Ukraine has its Strategy for Sustainable Development "Ukraine 2020" which includes top10 priorities such as: reform of national security and defense system; renewal of authorities and anti-corruption reform; judicial and law enforcement reform, decentralization and public admin- 
Table 2. SWOT-analysis of SME Development Policy Implementation in Ukraine, 2016

\begin{tabular}{|c|c|}
\hline Strengths & Weaknesses \\
\hline 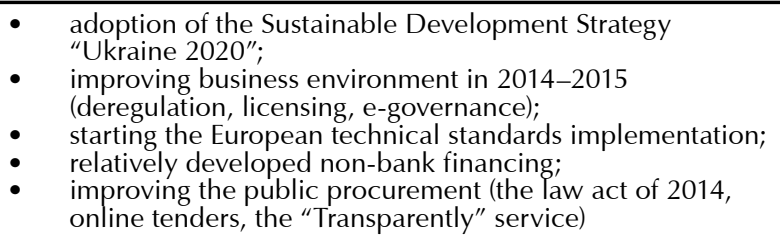 & $\begin{array}{l}-\quad \text { lack of overall structured, coherent SME development } \\
\text { policy; } \\
\text { regulatory barriers (21 days to start a business, problems } \\
\text { with the customs, insolvency, complex judicial system, } \\
\text { corruption); } \\
\text { the low level of availability of debt capital; } \\
\text { lack of a coherent policy to stimulate innovation and } \\
\text { support of SMEs }\end{array}$ \\
\hline Opportunities & Thunders \\
\hline $\begin{array}{l}\text { - } \\
\text { EUreement on Free Trade Area between Ukraine and the } \\
\text { - } \quad \text { participation in Horizon } 2020 \text { and Enterprise Europe } \\
\text { Network; } \\
\text { - competitive and educated workforce; } \\
\text { the current education reform is aimed at long-term } \\
\text { advocacy and entrepreneurship development; } \\
\text { relatively developed market for SME development services } \\
\text { (business incubators, consulting) }\end{array}$ & $\begin{array}{l}\bullet \quad \text { military conflict in the east of the country, adversely } \\
\text { affecting the macroeconomic situation and investment } \\
\text { attractiveness; } \\
\text { unstable SMEs development policy (frequent change of } \\
\text { responsibility, initiative without funding or realization); } \\
\text { a high level of illegal shadow practices in all sectors of the } \\
\text { economy; } \\
\text { slow implementation of reform programs }\end{array}$ \\
\hline
\end{tabular}

istration reform; deregulation and development of entrepreneurship; health care reform; tax reform; energy independence; popularization of Ukraine in the world; promotion of state interests in the global information space. Unfortunately, the strategy of Ukraine doesn't define the innovation development as a priority at all.

Therefore, due to the advantages, which are mentioned above, we offer to reconsider the priorities of the Development Strategy of Ukraine. Among them should be space and aviation, ICT in industry, data analysis and information management, smart agriculture, biotechnologies in food production, etc. Ukrainian government policy should be directed at the support of these branches and appropriate ambitious startup ideas. The government should also encourage informal investors, including business angels and crowdfunding network, which play a key role in financing innovative SMEs in developed countries. This will force the development of innovative SMEs and make them more competitive in the global world.

Table 3. Roadmaps of development strategies in different countries

\begin{tabular}{|c|c|}
\hline Country & Development strategies \\
\hline Slovakia & $\begin{array}{l}\text { - } \quad \text { automotive \& mechanical engineering industries; } \\
\text { - } \quad \text { ICT and services; } \\
\text { - } \quad \text { consumer electronics and electrical equipment }\end{array}$ \\
\hline Latvia & $\begin{array}{l}\text { - } \quad \text { smart energy; } \\
\text { advanced ICT; } \\
\text { - } \quad \text { knowledge intensive bio-economy, biomedicine, medical technologies and biotechnology; } \\
\text { - } \quad \text { advart materials, technology and engineering; } \\
\text { advanced technologies in machine industries }\end{array}$ \\
\hline Hungary & $\begin{array}{ll}- & \text { ICN and information services; } \\
\text { - } & \text { sustainable environment; } \\
\text { - } & \text { agricultural innovation; } \\
\text { - } & \text { hear and renewable energies; } \\
& \text { healthy society and wellbeing, engineering }\end{array}$ \\
\hline Poland & $\begin{array}{l}\text { - } \quad \text { innovative agriculture and agro-food industry; } \\
\text { - } \quad \text { modern textile and fashion industry (including design); } \\
\text { - } \quad \text { pharmaceuticals and cosmetics (including health resort medicine) }\end{array}$ \\
\hline Estonia & $\begin{array}{l}\text { - } \quad \text { ICT inindustry - data analysis and information management; } \\
\text { e-health; } \\
\text { knowledge-based construction; } \\
\text { biotechnologies in food }\end{array}$ \\
\hline Romania & $\begin{array}{l}\text { - } \quad \text { agriculture and food industry; } \\
\text { - IT \& C; } \\
\text { automotive industry and other transport }\end{array}$ \\
\hline
\end{tabular}




\section{CONCLUSION}

The analysis of different statistical reports on SMEs development and innovations shows new global trends of development of high-tech SMEs. This fact demonstrates that Ukraine has all chances to join the global community. At the same time, the SWOT-analysis and survey of Ukrainian SMEs show that our main obstacle is poor government support of both innovations and SMEs. This proves needs to enforce it due to the types of government support:

- political (to improve the policy and strategy in the field of entrepreneurship encouraging to start business and to develop it due to the policy's priorities; increasing knowledge and experience sharing among SMEs, large enterprises, scientific organizations and universities; creating conditions for decentralization networking and integration of local SMEs to global knowledge network; designing incentives for local SMEs not to move abroad with their high-tech development products and to satisfy Ukrainian market);

- legislative (to improve and design modern laws, roles, short-term and long-term strategies, codes of ethics for protection investors' and creditors' rights; to enforce punitive measures for those who violates intellectual property rights);

- economical (to expand the set of financial instruments and then promote its inclusivity: sign contracts with SMEs for innovative products, provide interest-free lending, special tax regimes (tax holidays, low interest rates, tax credits), government guarantees, insurance risks' innovations, compensation for losses of profit).

- The tandem of such types of government support in Ukraine will make it possible to enter new era of high-tech development, to strengthen its positions in a global competitive world, to increase the level of local consumers' absorption capacity to innovations. In general, well-balanced government policy of supporting innovations will contribute to improving wellness, prosperity and achieving goals of sustainable development in Ukraine.

\section{REFERENCES}

1. AGE Global Enterprise Recognition Report (2015). Retrieved from http://dnbsmallbusiness.com.au/ News/SMEs_call_for_universal_definition_of_small_business/ indexdl_8518.aspx

2. Bloem, J., M. van Doorn, Duivestein, S. (2014). The Fourth Industrial Revolution. Things to Tighten the Link Between IT and OT. Groningen: Sogeti VINT Production.

3. Britchenko, I. G., Momot, O. M., \& Sayenko, V. G. (2012). Economic problems of business function development in the sectors of national economy. DonetskPoltava: OOO “Tehservis".

4. Chien, C. (2012). Startups and Patent Trolls. Retrieved from http:// digitalcommons.law.scu.edu/cgi/ viewcontent.cgi?article $=1554 \&$ con text=facpubs

5. Dittrich, P. (2016). Reskilling for the fourth industrial revolution. Formulating a European strategy. Retrieved from http://www.institutdelors.eu/media/digitalskilljdib-nov2016.pdf?pdf=ok

6. Economic and Industry Outlook for the Second Half of 2017 (2017. August). Retrieved from http://eng. kiet.re.kr/kiet_eng/?sub_num=21 0 \&state $=$ view\&id $x=53623$ \&ord $=0$

7. Fairlie, R., \& Reedy, E. (2016). The Kauffman Index: Startup Activity: national trends. Retrieved from file:///C:/Users/PC/Desktop/\%D $0 \% 90 \% \mathrm{D} 0 \% \mathrm{BD} \% \mathrm{D} 1 \% 82 \% \mathrm{D} 0 \% \mathrm{~B}$ E\%D0\%BD\%D1\%8E\%D0\%BA/ kauffman_index_startup_activity_metro_trends_2016.pdf

8. Frolov, S., Hovorun, A., \& Ostapenko, M. (2017). Prospects for the innovative development of information technology in Ukraine during economic crisis. Innovative Marketing, 13(1), 55-60. httpx://doi.org/10.21511/ im.13(1).2017.05

9. Growing the global economy through SMEs (2011). Retrieved from http://www.edinburghgroup.org/media/2776/ edinburgh_group_research_-_ growing_the_global_economy_ through_smes.pdf)

10. Information economy report (2017). Digitalization, trade and development. UNCTAD, 2017, 129 p. 
11. Kushnir, K., Mirmulstein, M. I., \& Ramalho, R. (2010). Micro, Small, and Medium Enterprises Around the World: How Many Are There, and What Affects the Count? Retrieved from http://www.ifc.org/ wps/wcm/connect/9aeldd8049586 0d6a482b519583b6d16/MSME-CIAnalysisNote.pdf?MOD=AJPERES

12. Moavenzadeh, J. (2015, October). The 4th Industrial Revolution: Reshaping the Future of Production. Retrieved from https://www.eiseverywhere.com/ file_uploads/fe238270f05e2dbf187e2a60cbcdd68e_2_Keynote_ John_Moavenzadeh_World_Economic_Forum.pdf

13. Muller, P., Devnani, Sh., Julius, J., Garliardi, D., \& Marzocchi, Ch. Annual Report on European SMEs 2015/2016. Retrieved from https://ec.europa.eu/jrc/sites/ jrcsh/files/annual_report_-_eu_ smes_2015-16.pdf

14. Olefirenko, O. (2016). Methodic tools to optimize marketing ex- penses of the innovatively active industrial enterprises in Ukraine. Problems and Perspectives in Management, 14(1). https://doi. org/10.21511/ppm.14(1).2016.05

15. Richards, C. (2016). What is the 4th Industrial Revolution (4IR). Retrieved from https://www.eef. org.uk/campaigning/news-blogsand-publications/blogs/2016/ aug/what-is-the-4th-industrialrevolution

16. Schwab, K. (2015). The Fourth Industrial Revolution. What it means and how to respond? Snapshot.12. Retrieved from http://www.vassp.org.au/webpages/Documents2016/PDevents/ The $\% 20$ Fourth $\% 20$ Industrial\%20 Revolution\%20by\%20Klaus\%20 Schwab.pdf

17. Schwab, K. (2017). The Fourth Industrial Revolution. New York (NY): Crown Business, 2017.

18. The Economist Intelligence Unit (2010). Retrieved from http:// country.eiu.com/article.aspx?artic leid $=1625603146 \&$ Country=Japa n\&topic $=$ Business\&subtopic $=$ Bus iness+environment\&subsubtopic $=$ Rankings+overview

19. User Guide to SME Definition (2016). Retrieved from:http:// ec.europa.eu/regional_policy/ sources/conferences/state-aid/ sme/smedefinitionguide_en.pdf

20. Wang, Y. (2016). What are the biggest obstacles to growth of SMEs in developing countries? A picture emerging from an enterprise survey. Retrieved from http://ies.fsv.cuni.cz/default/file/ download/id/30120

21. Yurynets, Z. (2016). Forecasting model and assessment of the innovative and scientifictechnical policy of Ukraine in the sphere of innovative economy formation. Investment Management and Financial Innovations, 13(2). https://doi. org/10.21511/imfi.13(2).2016.02 